\title{
A Decade of Lean Six Sigma (LSS) in Healthcare: Past Review, Current State and Future Perspective
}

\author{
Ritika Rathore \\ Research Scholar, Amity Business School, \\ Amity University Noida UP (India)
}

\author{
Dr. Abhay Kumar Srivastava \\ Associate Professor, \\ IPE Hyderabad Telangana (India)
}

\begin{abstract}
In the past decade, a number of healthcare setups have adopted LSS methodology to reduce wastages and improve efficiency in the service delivery and patient flow. But there is partial research done on understanding the sequence to be followed by healthcare organizations to implement LSS in their different departments. The applicability of various LSS tools in different kinds of healthcare settings is also not conclusive. This article focuses on mending this gap by mapping the current state of LSS in healthcare and identifies directions for future research. The authors have explained key concepts of LSS and investigated the existing knowledge of LSS implementation between 2006 and 2018 in various healthcare settings all over the world to answer key research questions on the application of LSS in various healthcare areas. Further, this paper is one of the first comprehensive studies that attempted to tabulate the LSS tools and techniques used in different healthcare delivery areas. The paper concludes that different healthcare services poses different types of challenges for LSS implementation due to their distinctive service delivery, but a single framework can be applied with a slight change in the usage of tools and techniques within the steps of that framework. Also, research opportunities exist to determine the appropriate path which a hospital should follow while implementing LSS, to identify the most suitable set of LSS tools and thereby empirically validating the benefits of LSS.
\end{abstract}

Key Words: Lean Six Sigma, DMAIC, Healthcare, LSS tools, Lean Management, Six Sigma Methodology

\section{INTRODUCTION}

Healthcare sector constitutes a vast proportion of the entire service industry with some unique features. Here the patients and their relatives are the customers and the health care services have direct effect on them. The entire healthcare sector worldwide is expanding at a vigorous pace because of its spiraling coverage, services and mounting expenditure by public as well private players. In past two decades, many advances have taken place in the medicine field but still the quality of health service in ensuring patient safety and addressing patient needs has continued to be below the level of acceptance. Hence, in today's scenario, continuous and systematic improvement is imperative in healthcare sector for it to remain costeffective and efficient, and provide high-quality services.

It is known that the continuous quality improvement techniques from manufacturing like Lean and Six Sigma have been applied in healthcare(Glasgow, Scott-Caziewell, \& Kaboli, 2010). The application of Continuous
Improvement techniques is increasing in popularity in the health sector (Langabeer, DelliFraine, Heineke, \& Abbass, 2009). More than $90 \%$ of healthcare processes are those that do not add value and hence leaves a considerable space for improvement in efficiency. To solve different kinds of problems, TQM and Continuous improvements techniques have proved to be successful in improving the healthcare service delivery and ensuring patient safety along with increasing employee satisfaction and competitive environment. (Lighter, 2011) Based on the publication frequency, Lean, Six-Sigma and Lean Six Sigma are the most frequently used CI techniques to improve the quality in hospitals(Glasgow et al., 2010). (Henke, 2009) reported that lean management initiative has been used in about $50 \%$ of US hospital cases to improve quality while other research papers explain application of six-sigma in healthcare setup for standardized processes. (Proudlove, Moxham, \& Boaden, 2008)

\section{Lean Management}

Many types of quality management concepts have been developed so far and lean concept is one of the most widely used and successfully implied. Lean Management is a continuous improvement strategy which is performance based and focuses on eliminating wastes by keeping into account customer's needs.

Lean is defined as a systematic approach towards identifying waste and eliminating them through continuous improvement thereby making the product flow with customer pull to achieve perfection.

Lean is an extremely powerful concept that aims to maximize operational efficiency, quality, speed and cost (Holweg, 2007). Also, lean healthcare implementations resulted in wait time reduction, reduction in the time of stay of the patients, increase in capacity and cost reduction (Mazzocato et al., 2012). The same authors report that the Value Stream Mapping (VSM), Kaizen events and work standardization are among the most used lean tools in hospital environments. Recently, in their lean healthcare literature review,(Costa, Filho, Rentes, Bertani, \& Mardegan, 2017) indicated that reducing patient lead times, reducing costs and making financial improvements were the primary motivators for lean implementation in healthcare. 


\section{Six-Sigma}

Motorola Inc. in 1987 introduced and implemented the concept of six-sigma to improve quality. Six-Sigma measures quality by defects per million opportunities (DPMO) in the manufacturing sector, while in services sector it aims at reducing variations in the process. To minimize the errors and move towards excellence, most of the corporate hospitals are today operating at three Sigma or four Sigma quality levels. Six Sigma methods can reduce variability and waste in the process thereby reducing errors and improving customer satisfaction. It can provide more efficient processes which would lead to greater satisfaction rate among patients and happy and satisfied employees (R. \& Mallikarjun, 2011). Six Sigma methods apply the statistical methods to achieve uniformity and preciseness in the processes. It also imparts the training and certification of designated process specialists (e.g. green belts, black belts) within organization to help guide Six Sigma improvement efforts.

\section{Lean and Six- sigma}

Lean and Six-Sigma when combined, can give better results than the individual application of the either of the two. The integrated approach works well than previous approaches because it integrates the human (such as leadership, customer focus, cultural change, etc.) and process aspects (process management and capability, metrics driven thinking) for improvement (Antony, 2011). It is essential to combine the two approaches because lean concept alone cannot reduce variability by bringing the process under statistical control and six sigma alone cannot make a process more efficient by reducing time and money invested (George, 2002). LSS methodology makes use of DMAIC cycle to ensure the basic groundwork for servicequality improvement (Su et al., 2006). LSS uses quality control tools from both methodologies, thereby, enhancing speed of the process while also increasing accuracy (Mader, 2008). LSS has proved to be pretty successful in the manufacturing sector in past two decades but its application in the service sector and particularly healthcare sector has been limited (Patton, 2005; Antony and Kumar, 2012). The application of LSS in manufacturing sector has been substantiated by ample evidences; however, the application of LSS methodologies within healthcare sector has partial empirical evidence. (Gijo et al., 2013; Gijo and Antony, 2013) The integrated approach focuses on process centric and statistically data driven basis of both lean and six-sigma simultaneously.

A clear difference between lean and Six Sigma is that they deal with different kinds of problems. While lean focuses on improving the value stream, the patient flow, trying to eliminate wastes and bringing the problems visible (Arthur, 2011), six sigma focuses on precision and accuracy, in specific points of the processes, with statistical tools to improve the quality, while reducing the variation in performance (Antony \& Kumar, 2012). However, both focus on customer needs, reducing costs and improving processes (Arthur, 2011). So, in the last decade, a great tendency in CI in healthcare organizations is the combination of lean with Six Sigma. (Bisgaard, 2009)
This article addresses the following research questions:

Research Question 1: Which LSS tools have been used in healthcare so far? How can they be classified?

Research Question 2: How can LSS benefit healthcare? For what purpose(s), had it been recommended in healthcare literature?

\section{RESEARCH METHODOLOGY}

For the search criteria, the combination of following words was used.

'Lean' or 'Six Sigma' or 'Lean Six Sigma' and 'healthcare' or 'health care' or 'hospital' and 'survey' or 'single case study' or 'multiple case study' or 'action research'. This research paper uses a selective literature review process as suggested by (Daultani, Chaudhuri, \& Kumar, 2015), as it allows to comprehend the conceptual advancement in the field. Element of study has been taken as a single journal article. Initiation of LSS in healthcare has been traced to 2005-2006 by (Heuvel, Does, \& Koning, 2006) and (Arnheiter \& Maleyeff, 2005). Hence, we set 2006 as a starting point for the purpose of this article. Article titles and abstracts were checked for the inclusion at this stage. Published literature generally contains inter-linkages. We, therefore, used journal articles for cross-reference search. This was done using 'PubMed', 'Google Scholar' and 'Google Hand search'.

167articles were considered, and after deleting the duplicate articles between the databases, 118 articles were selected in 68 journals. These papers composed of the final list of works considered in the bibliographic review conducted in this paper. The systematic research was carried out between July and September 2019. In order to keep track of the publications that could occur during 2019 (work development), research alerts were created in the databases, so that authors could pursue publications associated to the original research scope.

It was observed that the first empirical research article in the field of Lean Six Sigma appeared in the journal 'Quality and Reliability Engineering International' in the year 2004. Over the last 15 years, the number of empirical research articles published on this subject has seen an exponential growth. To have some idea, the number of empirical research articles published between 2011 and 2017 represents $78 \%$ (93 articles) of the amount of articles considered in this paper, while only $22 \%$ (25 articles) are articles published between 2004 and 2010. The distribution of research articles on Lean Six Sigma in healthcare environments according to the year of publication is demonstrated in Figure 1. The histogram clearly indicates that the growth of the empirical research articles in the last five years is continuously increasing. The highest numbers of published articles were found in year 2015. The year 2019 is not being considered, since the bibliographic research was carried out between June and September 2019 , and even with the warnings created in the databases, some articles may be missing.

The numbers of selected publications taken from 2006 to 2018 (up to December) are shown in Figure 1. 


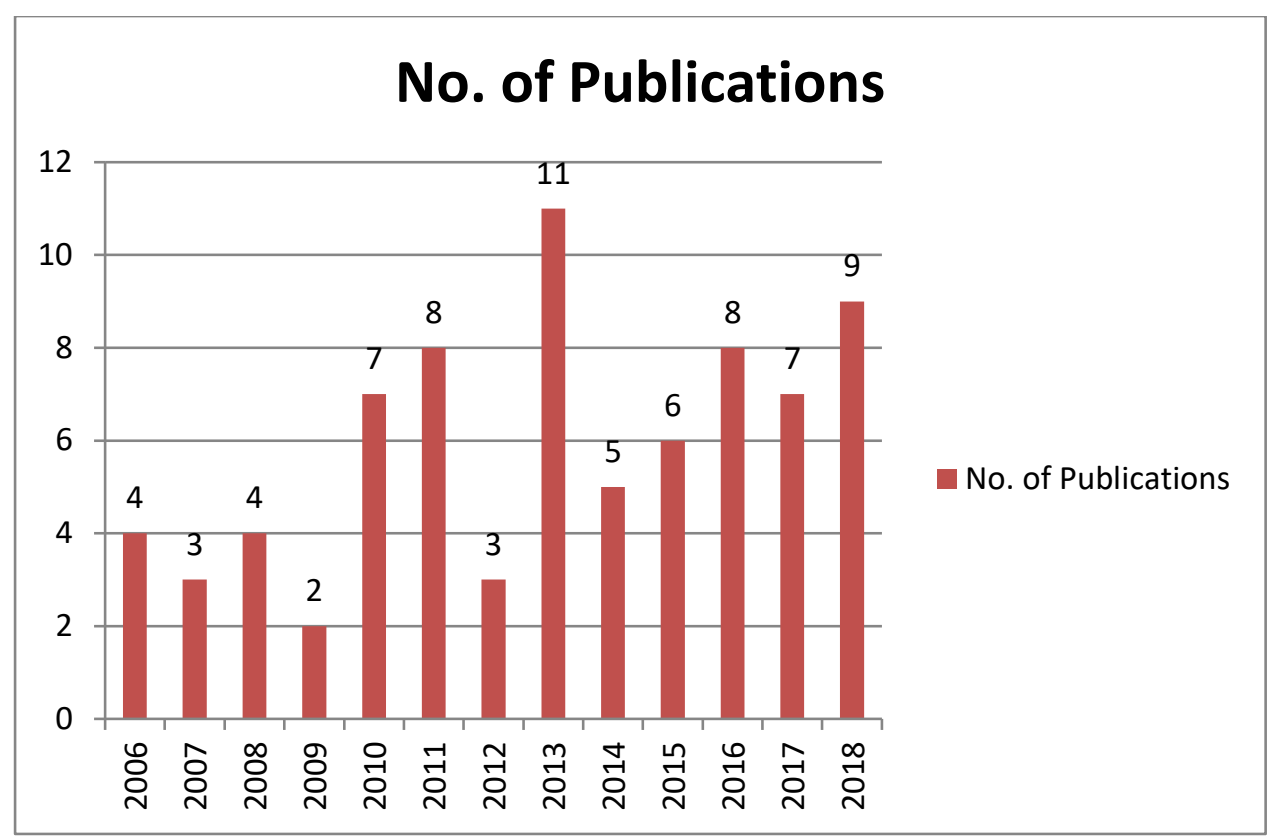

Figure 1

Each main article has been analyzed thoroughly to understand the potential of LSS (lean Six Sigma) in healthcare. As per the research method being followed, these papers can be classified as: action research (single or multiple case), empirical study, exploratory research, literature review papers and theoretical study. Above 50 per cent of the papers fell under action research (Single Case), which demonstrates cohesion between researchers and healthcare organizations. Number of papers in each of the categories is shown in Figure 2.

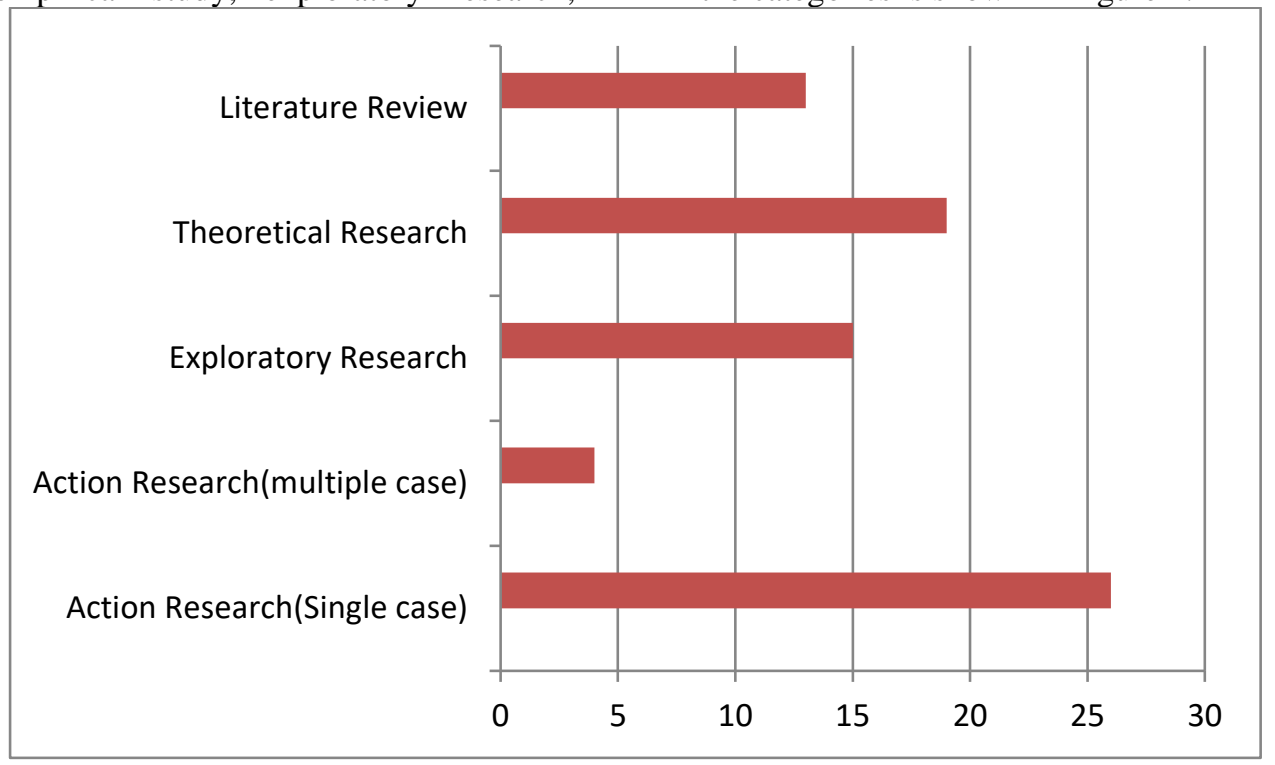

Figure 2

- There were many studies where researchers discussed about LSS implementation across the hospital but present concrete results for only a single department or case. All these studies have been referred to as single case action research. Studies reporting concrete results for more than one department/ medical facility have been considered as multiple case action research.

- Works which focused primarily on exploring LSS potential, effects, challenges and limitations have been categorized as exploratory research studies. While (Drohomeretski, Gouvea Da Costa, Pinheiro De Lima, \& Garbuio, 2014) studied LSS application in manufacturing industries, (Chaurasia, Garg, \& Agarwal, 2017) explored LSS potential in healthcare sector. (Schweikhart\& Dembe, 2009) explored the applicability of Lean and Six-sigma to clinical and translational research. (Pocha, 2010) concentrated on the limitations of the LSS methodology in a veterans medical center.(Honda, Bernardo, Gerolamo, \& Davis, 2018) introduced trends, benefits and limitations related to LSS implementation in healthcare environment.

- (Hseng-Long Yeh, Lin, Su, \& Wang, 2011) conducted an empirical study and showed that 
hospitals can increase their service quality and hence market competitiveness by implementing LSS methodology. (Langabeer et al., 2009) observed quality initiatives of LSS from the perspective of goal theory and thus help understand how lean and six-sigma complement each other in the healthcare sector. They further commented that whenever physicians were involved in quality improvement projects, they resisted efficiency improvement efforts rather than process improvement efforts. However, their contribution is important in understanding the basic concepts, and hence, they were categorized as theoretical papers.

- (Deblois \& Lepanto, 2016) collated the use of lean and six-sigma in acute care. Similarly, (Amaratunga \& Dobranowski, 2016) reviewed the application of lean and six sigma in Radiology. (Mason, Nicolay, \& Darzi, 2015) systematically reviewed the use of lean and six sigma in surgery department of a hospital while (Albliwi, Antony, Lim, \& van der Wiele, 2014) found out hindrances and failure factors in LSS implementation through systematic literature review. All these papers were categorized as literature review papers.

\section{FINDINGS AND DISCUSSION}

Research Question 1: Which LSS tools have been used in healthcare? How can they be classified?

Every LSS application started with formation of an interdisciplinary project team which consists of the specialists from different departments, Black belt in LSS /Green belt/champion.

The most common LSS framework that has been used in more than $80 \%$ of the researched articles is DMAIC (Define-Measure-Analyze-Improve-Control).The Define phase is where the scope of the project charter is developed. The goal of the Measure phase is to understand and baseline the current process. The data collected in the Measure phase is worked upon to identify the root causes of the problems in the Analyze Phase. In the Improve phase, the improvement recommendations are developed and implemented. The goal of the Control phase is to ensure that the improvements had a positive impact and that they will be sustained and controlled.

The following steps of DMAIC can broadly define the LSS roadmap. (Furterer, 2014)

Table 1

\begin{tabular}{|c|c|c|c|c|}
\hline Define & Measure & Analyze & Improve & Control \\
\hline $\begin{array}{l}\text { 1. Make project charter } \\
\text { 2. Carry out stakeholders } \\
\text { analysis } \\
\text { 3. Execute initial Voice of } \\
\text { Customer (VOC) and } \\
\text { identify Critical to } \\
\text { Quality factors (CTQ) } \\
\text { 4. Select the team } \\
\text { members and commence } \\
\text { the project } \\
\text { 5. Develop project plan. }\end{array}$ & $\begin{array}{l}\text { 1. Identify the current } \\
\text { process } \\
\text { 2. Describe the complete } \\
\text { VOC } \\
\text { 3. identify the Voice of } \\
\text { the Process (VOP) and its } \\
\text { existing performance } \\
\text { 4. confirm the } \\
\text { measurement system }\end{array}$ & $\begin{array}{l}\text { 1. Develop cause and } \\
\text { effect relationships } \\
\text { 2. Establish and } \\
\text { validate root causes } \\
\text { 3. Find out process } \\
\text { capability. }\end{array}$ & $\begin{array}{l}\text { 1. Classify improvement } \\
\text { recommendations by team } \\
\text { 2. Perform cost benefit analysis } \\
\text { 3. Devise future state } \\
\text { 4. Set up performance targets } \\
\text { and project scorecard } \\
\text { 5. Gain approval to implement } \\
\text { from upper management, then } \\
\text { implement } \\
\text { 6. Impart training and execute. }\end{array}$ & $\begin{array}{l}\text { 1. Calculate results and } \\
\text { supervise change } \\
\text { 2. Report project } \\
\text { scorecard data and } \\
\text { make process control } \\
\text { plan } \\
\text { 3. Apply P-D-C-A } \\
\text { process } \\
\text { 4. Develop future } \\
\text { plans. }\end{array}$ \\
\hline
\end{tabular}

Table 2

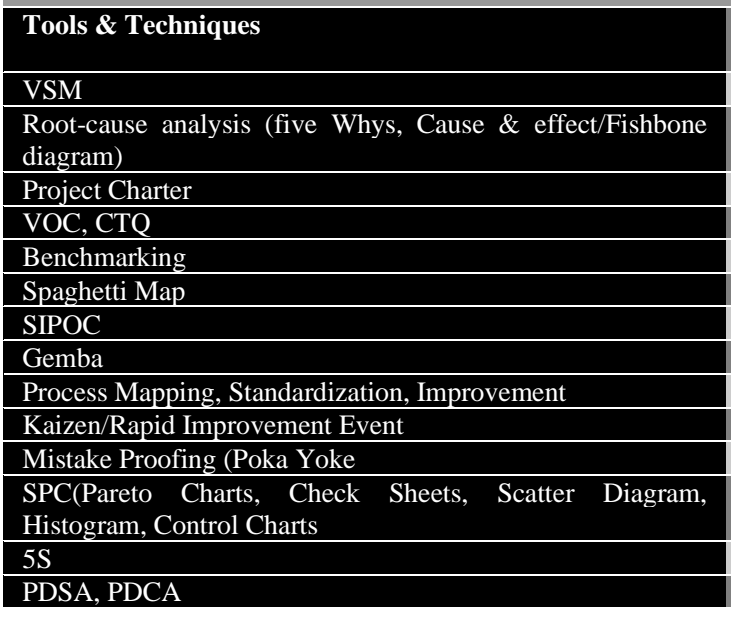

Table 2 above classifies the different tools and techniques used in LSS framework. It may be noted that defining the project charter and SIPOC (Supplier- Input-ProcessOutput-Customers) predominantly features in Define Phase, Statistical processes are used in Measure, Analyze

TOOL CLASSIFICATION

\begin{tabular}{|c|c|c|c|c|c|}
\hline \multicolumn{6}{|c|}{ TOUL CLASSIFICATION } \\
\hline $\begin{array}{l}\text { No. of } \\
\text { journal }\end{array}$ & D & $\mathbf{M}$ & $\mathbf{A}$ & I & $\mathrm{C}$ \\
\hline 8 & $\sqrt{ }$ & & & & \\
\hline 12 & $\sqrt{ }$ & & $\sqrt{ }$ & $\sqrt{ }$ & \\
\hline 14 & $\sqrt{ }$ & & & & \\
\hline 9 & $\sqrt{ }$ & & & & \\
\hline 2 & & & & $\sqrt{ }$ & $\sqrt{ }$ \\
\hline 1 & & & & & \\
\hline 10 & $\sqrt{ }$ & & & & \\
\hline 3 & $\sqrt{ }$ & $\sqrt{ }$ & & & \\
\hline 7 & & & $\sqrt{ }$ & $\sqrt{ }$ & $\sqrt{ }$ \\
\hline 2 & & & & $\sqrt{ }$ & $\sqrt{ }$ \\
\hline 1 & & & & $\sqrt{ }$ & $\sqrt{ }$ \\
\hline 22 & & $\sqrt{ }$ & & $\sqrt{ }$ & $\sqrt{ }$ \\
\hline 1 & & $\sqrt{ }$ & $\sqrt{ }$ & & \\
\hline 2 & & & & & $\sqrt{ }$ \\
\hline
\end{tabular}

and Control Phases. Root- cause analysis is predominantly used in analyze phase and Process mapping and Standardization defines the Improve and Control Phase. 
Research Question 2: How can LSS benefit healthcare? For what purpose(s), had it been recommended in healthcare literature?

Lean Six Sigma has shown how very different and disparate tools can provide a holistic and integrated toolkit for solving complex problems in healthcare. In this paper, we have narrowed upon the typical DMAIC Six Sigma problem solving methodology, for strategically important, non-standardized, complex, and cross-functional problems.

The LSS methodologies were executed in following healthcare areas:

- Radiography department

- Oncology Department

○ Repositioning before radiotherapy

- Head CT orders

- Pediatric Operating Room

- Surgery Department

○ Cataract Surgery

- Prosthetic Hip-replacement surgery

- Pediatric Clinic
- Cardiac Catherization Lab

- Administrative Department- Medical Records

○ Registration Process

- Emergency Department

- General - To reduce patient wait times in OPD

$\circ$ Increase hand hygiene compliance and reduce MRSA Infection

- Safety Awareness

- Referral Process

- Post-Anesthesia Care

- Acute Care

- Ophthalmology Clinic

- Internal Medicine Residency Clinic

A comprehensive table, Table 3 , is created which details the application of LSS methodology in the different healthcare areas in different parts of the world. The findings suggest the use of DMAIC methodology for streamlining various processes and reducing errors. 


\begin{tabular}{|c|c|c|c|c|}
\hline S.No & Author & Place of study & $\begin{array}{l}\text { Table } 3 \\
\text { Area of application of LSS }\end{array}$ & Methodology adopted \\
\hline 1. & (Mancosu et al., 2018) & $\begin{array}{l}\text { Radiotherapy Department, } \\
\text { Clinical and Research } \\
\text { Hospital, Italy }\end{array}$ & $\begin{array}{l}\text { To redesign breast repositioning } \\
\text { process (Lean) by the retrospective } \\
\text { analysis of the database (Six } \\
\text { Sigma) }\end{array}$ & $\begin{array}{l}\text { DMAIC } \\
\text { Define: Problem Statement identified detailing the CTQ characteristics } \\
\text { Measure: Current process was quantified, establishing the reference baseline } \\
\text { Analyze: Statistical Analysis (STATA software), Fishbone diagram } \\
\text { Improve: Reduction of errors by the Poka-Yoke implementation. } \\
\text { Control: Implementing control systems as statistical process control, visual workplaces, Kaizen. }\end{array}$ \\
\hline 2 & $\begin{array}{l}\text { (Steere, Rousseau, \& } \\
\text { Durland, 2018) }\end{array}$ & 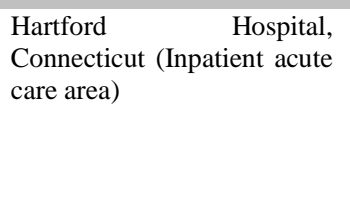 & $\begin{array}{l}\text { To improve infusion therapy } \\
\text { practices by IV team }\end{array}$ & $\begin{array}{l}\text { DMAIC } \\
\text { Define: opportunity for improvement, project goals, and patient requirements. } \\
\text { Measure: Data collection of all cost incurred and performance measurement } \\
\text { Analyze: Root cause analysis } \\
\text { Improve: process performance by addressing and eliminating the root causes } \\
\text { Control: by building a system of checks and adjustments for ongoing improvement in the process }\end{array}$ \\
\hline 3. & (Godley \& Jenkins, 2018) & $\begin{array}{l}\text { Vascular interventional } \\
\text { radiology (VIR) department, } \\
\text { Community Hospital, USA }\end{array}$ & $\begin{array}{l}\text { To improve processes to de-crease } \\
\text { wait times and increase patient } \\
\text { satisfaction in the VIR department. }\end{array}$ & $\begin{array}{l}\text { DMAIC } \\
\text { Define: Project Team, Project Charter, Gemba } \\
\text { Measure: Process mapping \&Data collection } \\
\text { Analyze: FMEA } \\
\text { Improve: Changes proposed after brainstorming } \\
\text { Control: Monitoring and Data review after two weeks }\end{array}$ \\
\hline 4. & (Montella et al., 2017) & $\begin{array}{l}\text { University Hospital, Naples, } \\
\text { Italy }\end{array}$ & $\begin{array}{l}\text { To reduce the incidence of health } \\
\text { Associated Infections (HAIs) }\end{array}$ & $\begin{array}{l}\text { DMAIC } \\
\text { Define: SIPOC, Gantt Chart and Focus group to identify CTQs } \\
\text { Measure: Data collection } \\
\text { Analyze: Control charts, histograms, Statistical tests( Chi-square and Fischer test), Scatter plot } \\
\text { Improve: Weighted variable analysis } \\
\text { Control: Monitoring using process indicators }\end{array}$ \\
\hline 5. & (Chaurasia et al., 2017) & $\begin{array}{l}\text { Chemotherapy oncology } \\
\text { department in a cancer } \\
\text { hospital in Delhi }\end{array}$ & $\begin{array}{l}\text { Reduction in waiting time of } \\
\text { patients undergoing chemotherapy, } \\
\text { increased patient satisfaction and } \\
\text { overall cost reduction in hospital }\end{array}$ & $\begin{array}{l}\text { DMAIC } \\
\text { Define: Project charter, SIPOC, VOC translation matrix, tree diagram } \\
\text { Measure: Data collection plan, check-sheets, value stream mapping } \\
\text { Analyze: Check sheet, data analysis, cause \& effect diagram, VSM } \\
\text { Improve: Weighted criteria matrix, PDCA } \\
\text { Control: Control Plan, Documentation }\end{array}$ \\
\hline 6. & $\begin{array}{l}\text { (Tagge, Thirumoorthi, } \\
\text { Lenart, Garberoglio, \& } \\
\text { Mitchell, 2017) }\end{array}$ & $\begin{array}{ll}\text { Academic } & \text { Children's } \\
\text { Hospital } & \\
\text { California, USA } & \end{array}$ & $\begin{array}{l}\text { Improvement in efficiency of the } \\
\text { operating room }\end{array}$ & $\begin{array}{l}\text { DMAIC } \\
\text { Define: Project Charter, process Map, SIPOC } \\
\text { Measure: Data collection from EMR, Histogram } \\
\text { Analyze: fishbone diagrams, scatter plots, box and whisker plots, histograms, Pareto charts } \\
\text { Improve: Identified nine process changes to improve. } \\
\text { Control: Turnover time and turnaround time were kept as measures to check impact of change. }\end{array}$ \\
\hline 7. & (Agarwal et al., 2016) & $\begin{array}{l}\text { Tertiary Care Cath Lab, } \\
\text { India }\end{array}$ & $\begin{array}{l}\text { To improve the efficiency and } \\
\text { patient throughput of Cath-Lab } \\
\text { Operation }\end{array}$ & $\begin{array}{l}\text { Process Improvement using lean tools like } \\
\text { Challenge } \\
\text { Kaizen } \\
\text { Genchi Genbutsu } \\
\text { Reduction Of waste }\end{array}$ \\
\hline 8. & (Jayasinha, 2016) & $\begin{array}{l}\text { Olive View-UCLA Medical } \\
\text { Center Pediatric Clinic }\end{array}$ & $\begin{array}{l}\text { To restructure and redesign the } \\
\text { clinic for improved care delivery }\end{array}$ & $\begin{array}{l}\text { Project team } \\
\text { LSS tools like } 5 \text { S methodology, flow chart, spaghetti charts, Voice of customer }\end{array}$ \\
\hline 9. & (Tekes et al., 2016) & $\begin{array}{l}\text { Quaternary care, Academic } \\
\text { children's center }\end{array}$ & $\begin{array}{l}\text { To reduce the use of CTs in the } \\
\text { population of patients with } \\
\text { hydrocephalus by } 50 \% \text { within } 6 \\
\text { months }\end{array}$ & $\begin{array}{l}\text { DMAIC } \\
\text { Define: Project title, problem statement, scope of the work } \\
\text { Measure: Data collection } \\
\text { Analyze: Control charts, histograms, Statistical tests } \\
\text { Improve: Visual Flow chart, Gemba } \\
\text { Control: Monitoring }\end{array}$ \\
\hline
\end{tabular}




\begin{tabular}{|c|c|c|c|c|}
\hline 10. & (Jnanesh, 2016) & $\begin{array}{l}\text { Medical records department, } \\
\text { India }\end{array}$ & $\begin{array}{l}\text { To reduce the TAT of medical } \\
\text { records preparation process. } \\
\text { Improve the efficiency of } \\
\text { department }\end{array}$ & $\begin{array}{l}\text { DMAIC } \\
\text { Define: SIPOC, Gantt Chart and Focus group to identify CTQs } \\
\text { Measure: Data collection } \\
\text { Analyze: Control charts, histograms, Statistical tests( Chi-square and Fischer test), Scatter plot } \\
\text { Improve: Weighted variable analysis } \\
\text { Control: Monitoring using process indicators }\end{array}$ \\
\hline 11. & (Improta et al., 2015) & $\begin{array}{l}\text { Operation theatre, } \\
\text { Orthopedics \& } \\
\text { Traumatology, University } \\
\text { Hospital, Southern Italy }\end{array}$ & $\begin{array}{l}\text { Applying Lean Six Sigma for the } \\
\text { management of patients undergoing } \\
\text { prosthetic hip replacement surgery }\end{array}$ & $\begin{array}{l}\text { DMAIC } \\
\text { Define: Project charter, CTQ Identification, SIPOC } \\
\text { Measure: measurement of current process performance, Collection of retrospective data, } \\
\text { histograms, run charts } \\
\text { Analyze: Develop VSM and identify NVA, Fishbone diagram, brainstorming and statistical } \\
\text { analysis. } \\
\text { Improve: Standardization of discharge process, process plan with lean vision. } \\
\text { Control: Comparative statistical analysis, periodic review meetings, internal audit checklist, Run } \\
\text { chart is periodically updated. }\end{array}$ \\
\hline 12. & $\begin{array}{l}\text { (Habidin, Yahya, \& } \\
\text { Ramli, 2015) }\end{array}$ & $\begin{array}{l}\text { Emergency Department of a } \\
\text { hospital }\end{array}$ & $\begin{array}{l}\text { To improve emergency department } \\
\text { waiting time }\end{array}$ & $\begin{array}{l}\text { DMAIC } \\
\text { Define: Project Charter } \\
\text { Measure: Data collection } \\
\text { Analyze: Control charts, histograms, Statistical tests } \\
\text { Improve: Weighted variable analysis } \\
\text { Control: Monitoring using process indicators }\end{array}$ \\
\hline 13. & $\begin{array}{l}\text { (Bhat, Gijo, \&Jnanesh, } \\
\text { 2014) }\end{array}$ & $\begin{array}{l}\text { Hospital Information } \\
\text { Department of an Indian } \\
\text { Hospital. }\end{array}$ & $\begin{array}{l}\text { Apply LSS in OP-HID (Out- } \\
\text { patient-Hospital } \\
\text { department) to reduce waiting time } \\
\text { of patients. }\end{array}$ & $\begin{array}{l}\text { DMAIC } \\
\text { Define: Project charter, CTQ Identification, SIPOC } \\
\text { Measure: Data Collection plan to determine process sigma level. } \\
\text { Analyze: VSM prepared and NVA identified, Fishbone diagram, GEMBA method of validation. } \\
\text { Improve: Detailed Action plan and rounds } \\
\text { Control: Standardization and documentation of action plan }\end{array}$ \\
\hline 14. & $\begin{array}{l}\text { (Momani, Hirzallah, \& } \\
\text { Mumani, 2013) }\end{array}$ & 170 bedded hospital & $\begin{array}{l}\text { To develop a culture of safety and } \\
\text { quality according to international } \\
\text { standards }\end{array}$ & $\begin{array}{l}\text { DMAIC } \\
\text { Define: Project Team, Project Charter, } \\
\text { Measure: Data collection by individual and focus group interview } \\
\text { Analyze: Cause and effect diagram } \\
\text { Improve: Weighted variable analysis } \\
\text { Control: Monitoring using process indicators }\end{array}$ \\
\hline 15. & (Blick, 2013) & $\begin{array}{ll}\text { Oklahoma } & \text { University } \\
\text { Medical Center } & \end{array}$ & $\begin{array}{l}\text { To develop a fully automated core } \\
\text { laboratory, handling samples on } \\
\text { real-time basis with LSS } \\
\text { management tools }\end{array}$ & $\begin{array}{l}\text { Process improvement using LSS tools like } \\
\text { VSM, Process mapping etc. }\end{array}$ \\
\hline 16. & $\begin{array}{l}\text { (Laureani, Brady, \& } \\
\text { Antony, 2013) }\end{array}$ & Irish Hospital & $\begin{array}{l}\text { To examine and improve the } \\
\text { efficiency and effectiveness of } \\
\text { clinical \& administrative process } \\
\text { within the hospital. }\end{array}$ & $\begin{array}{l}\text { Process mapping; seven wastes; } 5 \mathrm{~S} \text { and logic tree. } \\
\text { Other techniques used were : } \\
\text { control charts; checklists and theory of constraints. }\end{array}$ \\
\hline 17. & $\begin{array}{l}\text { (Preethy, Diptee, Fretrik, } \\
\text { \& Nguyen, 2013) }\end{array}$ & VHA Medical Center, USA & $\begin{array}{l}\text { To improve the current systems and } \\
\text { processes for medication co- } \\
\text { management for dual care veterans. }\end{array}$ & $\begin{array}{l}\text { DMAIC } \\
\text { Define: define the problem, project goals and customer requirements } \\
\text { Measure: Data collection } \\
\text { Analyze: Root cause analysis } \\
\text { Improve: Elimination of root cause } \\
\text { Control: } \text { Monitoring using process indicators }\end{array}$ \\
\hline
\end{tabular}




\begin{tabular}{|c|c|c|c|c|}
\hline 18. & (R. \& Mallikarjun, 2011) & $\begin{array}{ll}\text { Multispecialty } & \text { Hospital, } \\
\text { Bangalore, India } & \end{array}$ & $\begin{array}{l}\text { Improving the quality of operation } \\
\text { theater }\end{array}$ & $\begin{array}{l}\text { DMAIC } \\
\text { Define: Project charter, High level process map, Measure: Data collection Plan (DCP) } \\
\text { Analyze: Data Analysis, Process Analysis, Fish bone diagram } \\
\text { Improve: Brain storming session } \\
\text { Control: Monitoring using supervisor control }\end{array}$ \\
\hline 19. & (Cima et al., 2011) & Mayo Clinic, Rochester, & $\begin{array}{l}\text { To improve the efficiency of OR } \\
\text { (operating Room) }\end{array}$ & $\begin{array}{l}\text { Study Design- } \\
\text { VSM, Process Improvement in } 5 \text { work streams identified }\end{array}$ \\
\hline 20. & $\begin{array}{l}\text { (Kuo, } \quad \text { Borycki, } \\
\text { Kushniruk, \& Lee, 2011) }\end{array}$ & $\begin{array}{l}\text { Post Anesthesia Care Unit, } \\
\text { Canada }\end{array}$ & $\begin{array}{l}\text { To improve workflow in post- } \\
\text { anesthesia work unit }\end{array}$ & $\begin{array}{l}\text { HLS3 } \\
\text { Identify, Analyze, Action } \\
\text { Follow-up }\end{array}$ \\
\hline 21. & $\begin{array}{l}\text { (Hseng-Long Yeh et al., } \\
\text { 2011) }\end{array}$ & $\begin{array}{l}778 \text { bedded, private hospital } \\
\text { in Taipei city, Taiwan }\end{array}$ & $\begin{array}{l}\text { To reduce the D2B (Door to } \\
\text { balloon ) time for STEMI (ST } \\
\text { elevation myocardial infection) } \\
\text { patients in cardiology department }\end{array}$ & $\begin{array}{l}\text { DMAIC } \\
\text { Define: Project charter, Customer requirements, High level flow chart (SIPOC) } \\
\text { Measure: Recording of time from the entry of patient to the balloon inflation, statistical analysis } \\
\text { Analyze: Check sheet, data analysis, cause \&effect diagram, VSM } \\
\text { Improve: Identify and implement solutions } \\
\text { Control: Monitoring }\end{array}$ \\
\hline 22. & $\begin{array}{l}\text { (Mandahawi, Al-Araidah, } \\
\text { Boran, \& Khasawneh, } \\
\text { 2011) }\end{array}$ & $\begin{array}{l}\text { Ophthalmology department } \\
\text { of a local hospital, Jordan }\end{array}$ & $\begin{array}{l}\text { To streamline processes and } \\
\text { enhance productivity of a hospital's } \\
\text { ophthalmology department. }\end{array}$ & $\begin{array}{l}\text { DMAIC } \\
\text { Define: SIPOC, Gantt Chart and Focus group to identify CTQs } \\
\text { Measure: Data collection } \\
\text { Analyze: Control charts, histograms, Statistical tests( Chi-square and Fischer test), Scatter plot } \\
\text { Improve: Weighted variable analysis } \\
\text { Control: Monitoring using process indicators }\end{array}$ \\
\hline 23. & (Fischman, 2010) & $\begin{array}{l}\text { Internal medicine residency } \\
\text { clinic }\end{array}$ & $\begin{array}{l}\text { To study workflow processes, } \\
\text { patient-physician relationship, and } \\
\text { appointment compliance to provide } \\
\text { quality care. }\end{array}$ & $\begin{array}{l}\text { PDSA Process } \\
\text { Plan, } \\
\text { Do } \\
\text { Study } \\
\text { Act }\end{array}$ \\
\hline 24.. & $\begin{array}{l}\text { (Niemeijer, Trip, KTB, } \\
\text { JMM, \& Wendt, 2010) }\end{array}$ & $\begin{array}{l}\text { University Medical Center } \\
\text { Groningen, Netherlands }\end{array}$ & $\begin{array}{l}\text { Improvement in discharge } \\
\text { procedure of the patients by } \\
\text { reducing length of stay at hospital }\end{array}$ & $\begin{array}{l}\text { DMAIC } \\
\text { Define: SIPOC } \\
\text { Measure: Translation of problem into measurable indicators called CTQs } \\
\text { Analyze: Checking the appropriateness of Length of Stay (LOS) using Appropriateness Evaluation } \\
\text { Protocol (D-AEP). } \\
\text { Improve: The result of analyze phase was communicated to care providers after } 2 \text { month for } \\
\text { improvement. } \\
\text { Control: As a process control plan, a dashboard was created to make admissions and average LOS } \\
\text { transparent and visible. }\end{array}$ \\
\hline 25. & $\begin{array}{l}\text { (Carboneau, Benge, Jaco, } \\
\& \text { Robinson, 2010) }\end{array}$ & $\begin{array}{l}\text { Presbyterian Healthcare } \\
\text { Services (PHS) in } \\
\text { Albuquerque, New Mexico }\end{array}$ & $\begin{array}{l}\text { Lean Six Sigma Improvement team } \\
\text { was chartered to increase hand } \\
\text { hygiene compliance to } 90 \%\end{array}$ & $\begin{array}{l}\text { DMAIC } \\
\text { Define: SIPOC, Obtaining VOC by asking questions from providers, staff, patients etc. and } \\
\text { converting them to CTQs } \\
\text { Measure: a) understanding current performance level by detailed process flow map .b) Narrow } \\
\text { down the list of potential root causes through Pareto Chart, Cause and Effect diagram and FMEA. } \\
\text { Analyze: Verify the key root causes by collecting and analyzing specific data. Statistical analysis } \\
\text { on staff education, hand hygiene culture and environmental surveillance. Use of one proportion } \\
\text { test. } \\
\text { Improve: Identify and implement solutions } \\
\text { Control: Monthly Control Plan, Safety coach program. }\end{array}$ \\
\hline
\end{tabular}




\section{CONCLUSION AND FUTURE RESEARCH DIRECTIONS}

Lean and Six Sigma have been used in tandem in healthcare to create improvements, but they go about it in different ways. Six-Sigma is primarily a statistics oriented method used to reduce errors and remove variations from medical processes involved in delivering care and service while lean is a process driven concept focusing on increasing efficiency by reducing waste. Both methodologies strive to optimize operations and increase value for patients. It is said that while Lean focuses on eliminating waste, Six Sigma seeks to impart standardization by decreasing defects to a specific statistical measure. In the last decade, the two systems have been combined into the hybrid improvement process called "Lean Six Sigma."

A number of tools and techniques of Lean and six-sigma are used to construct a LSS framework. But the most successful framework is DMAIC which is used for quality improvement in diverse departments. It is one framework which has the ability to become a standard roadmap of LSS owing to its vast applicability. The different constituents of DMAIC may vary and may be chosen from a collection of tools of lean and Six-Sigma depending on the project charter.

The application of Lean Six Sigma in healthcare prevents medical mistakes, decreases mortality rates, lessens lengths of stay, improves patient care and increases service quality. It has been observed that the application of LSS in single case basis of day to day operations at hospitals and clinics has been amazing. In LSS framework, Lean processes make processes more efficient by shortening wait times of patients, decreasing mortality rates, reducing hospital costs and increasing efficiency whereas Six sigma help standardize the process, thus making its implementation easy.

Most of the tools of Lean Six Sigma rely on data to know in depth problems: data is necessary to initiate any process improvement. The key issue is based on data integrity and on real time data. Big data allows to overcome limitations of traditional customer analysis tools (such as Quality Function Deployment) provides information on the entire "customer experience" and key visibility on VOCs (Voice of Customer).Therefore, the introduction of smart technologies allows clients, suppliers and employees to become real-time contributors to the data gathering exercise reducing the need for continuous controls. (Arcidiacono \& Pieroni, 2018).

Also, the application of LSS over different areas of healthcare enumerate the need to standardize the framework for its successful implementation over the entire sector rather a few success stories by means of single case studies.

LSS trainer- Master/black belt/champion should be made mandatory by the accreditation authorities for successful quality improvement initiatives.

With all these factors in account, LSS would prove to be very beneficial for improving the healthcare delivery.

\section{REFERENCES}

[1] Agarwal, S., Gallo, J. J., Parashar, A., Agarwal, K. K., Ellis, S. G., Khot, U. N., Kapadia, S. R. (2016). Impact of lean six sigma process improvement methodology on cardiac catheterization laboratory efficiency. Cardiovascular Revascularization Medicine. https://doi.org/10.1016/j.carrev.2015.12.011

[2] Albliwi, S., Antony, J., Lim, S. A. H., \& van der Wiele, T. (2014). Critical failure factors of lean Six Sigma: A systematic literature review. International Journal of Quality and Reliability Management, 31(9), 1012-1030. https://doi.org/10.1108/IJQRM09-2013-0147

[3] Amaratunga, T., \& Dobranowski, J. (2016). Systematic Review of the Application of Lean and Six Sigma Quality Improvement Methodologies in Radiology. Journal of the American College of Radiology. https://doi.org/10.1016/j.jacr.2016.02.033

[4] Antony, J., \& Kumar, M. (2012). Quality Innovation Prosperity / Kvalita Inovácia Prosperita Xvi/2-2012 Lean and Six Sigma Methodologies in Nhs Scotland: an Empirical Study and Directions for Future Research, 1745, 19-34. Retrieved from https://core.ac.uk/download/pdf/25973681.pdf

[5] Arcidiacono, G., \& Pieroni, A. (2018). The revolution Lean Six Sigma 4.0. International Journal on Advanced Science, Engineering and Information Technology, 8(1), 141-149.

[6] Arnheiter, E. D., \& Maleyeff, J. (2005). The integration of lean management and Six Sigma. The TQM Magazine, 17(1), 5-18. https://doi.org/10.1108/09544780510573020

[7] Bhat, S., Gijo, E. V., \& Jnanesh, N. A. (2014). Application of Lean Six Sigma methodology in the registration process of a hospital. International Journal of Productivity and Performance Management. https://doi.org/10.1108/IJPPM-11-2013-0191

[8] Blick, K. E. (2013). Providing critical laboratory results on time, every time to help reduce emergency department length of stay: How our laboratory achieved a six sigma level of performance. American Journal of Clinical Pathology, 140(2), 193-202. https://doi.org/10.1309/AJCPNUTIPQTRRG0D

[9] Carboneau, C., Benge, E., Jaco, M. T., \& Robinson, M. (2010). A lean Six Sigma team increases hand hygiene compliance and reduces hospital-acquired MRSA infections by $51 \%$. Journal for Healthcare Quality: Official Publication of the National Association for Healthcare Quality, 32(4), 61-70. https://doi.org/10.1111/j.1945-1474.2009.00074.x

[10] Chaurasia, B., Garg, D., \& Agarwal, A. (2017). Lean Six Sigma application in healthcare of patients. International Journal of Intelligent Enterprise. https://doi.org/10.1504/IJIE.2017.087670

[11] Cima, R. R., Brown, M. J., Hebl, J. R., Moore, R., Rogers, J. C., Kollengode, A., ... Deschamps, C. (2011). Use of Lean and Six Sigma Methodology to Improve Operating Room Efficiency in a High-Volume Tertiary-Care Academic Medical Center. Journal of the American College of Surgeons, 213(1), 83-92. https://doi.org/10.1016/j.jamcollsurg.2011.02.009

[12] Costa, L. B. M., Filho, M. G., Rentes, A. F., Bertani, T. M., \& Mardegan, R. (2017). Lean healthcare in developing countries: evidence from Brazilian hospitals. International Journal of Health Planning and Management, 32(1), e99-e120. https://doi.org/10.1002/hpm.2331

[13] Daultani, Y., Chaudhuri, A., \& Kumar, S. (2015). A Decade of Lean in Healthcare: Current State and Future Directions. Global Business Review. https://doi.org/10.1177/0972150915604520

[14] Deblois, S., \& Lepanto, L. (2016). Lean and Six Sigma in acute care: a systematic review of reviews. International Journal of Health Care Quality Assurance, 29(2), 192-208. https://doi.org/10.1108/IJHCQA-05-2014-0058

[15] Drohomeretski, E., Gouvea Da Costa, S. E., Pinheiro De Lima, E., \& Garbuio, P. A. D. R. (2014). Lean, six sigma and lean six sigma: An analysis based on operations strategy. International Journal of Production Research, 52(3), 804-824. https://doi.org/10.1080/00207543.2013.842015

[16] Fischman, D. (2010). Applying Lean Six Sigma Methodologies to. Quality Management in Health Care, 19(3), 201-210.

[17] Furterer, S. L. (2014). Lean six sigma case studies in the healthcare enterprise. Lean Six Sigma Case Studies in the Healthcare Enterprise. https://doi.org/10.1007/978-1-4471-5583-

[18] Glasgow, J. M., Scott-Caziewell, J. R., \& Kaboli, P. J. (2010). Guiding inpatient quality improvement: A systematic review of 
Lean and Six Sigma. Joint Commission Journal on Quality and Patient Safety, 36(12), 533-540. https://doi.org/10.1016/S15537250(10)36081-8

[19] Godley, M., \& Jenkins, jeanne B. (2018). Decreasing Wait Times and, $\quad 00(00), \quad 1-5$. https://doi.org/10.1097/NCQ.0000000000000332

[20] Habidin, N. F., Yahya, N. Z., \& Ramli, M. F. S. (2015). Using LSS DMAIC in improving emergency department waiting time. International Journal of Pharmaceutical Sciences Review and Research.

[21] Heuvel, J. Van Den, Does, R. J. M. M., \& Koning, H. De. (2006). Lean Six Sigma in a hospital. International Journal of Six Sigma and Competitive Advantage. https://doi.org/10.1504/IJSSCA.2006.011566

[22] Honda, A. C., Bernardo, V. Z., Gerolamo, M. C., \& Davis, M. M. (2018). How lean six sigma principles improve hospital performance. Quality Management Journal. https://doi.org/10.1080/10686967.2018.1436349

[23] Hseng-Long Yeh, Lin, C.-S., Su, C.-T., \& Wang, P.-C. (2011). Applying lean six sigma to improve healthcare: An empirical study. AFRICAN JOURNAL OF BUSINESS MANAGEMENT, 5(31). https://doi.org/10.5897/AJBM11.1654

[24] Improta, G., Balato, G., Romano, M., Carpentieri, F., Bifulco, P., Alessandro Russo, M., ... Cesarelli, M. (2015). Lean Six Sigma: A new approach to the management of patients undergoing prosthetic hip replacement surgery. Journal of Evaluation in Clinical Practice. https://doi.org/10.1111/jep.12361

[25] Jayasinha, Y. (2016). Decreasing Turnaround Time and Increasing Patient Satisfaction in a Safety Net Hospital - Based Pediatrics Clinic Using Lean Six, 25(1), 38-43. https://doi.org/10.1097/QMH.0000000000000083

[26] Jnanesh, S. B. E. V. G. N. A. (2016). Productivity and performance improvement in the medical records department of a hospital. International Journal of Productivity and Performance Management, 65(1), 98-125. https://doi.org/10.1108/S14793563(2012)000012B007

[27] Kuo, A. M. H., Borycki, E., Kushniruk, A., \& Lee, T. S. (2011) A healthcare lean six sigma system for postanesthesia care unit workflow improvement. Quality Management in Health Care. https://doi.org/10.1097/QMH.0b013e3182033791

[28] Langabeer, J. R., DelliFraine, J. L., Heineke, J., \& Abbass, I. (2009). Implementation of Lean and Six Sigma quality initiatives in hospitals: A goal theoretic perspective. Operations Management Research, 2(1), 13-27. https://doi.org/10.1007/s12063-009-0021-7

[29] Laureani, A., Brady, M., \& Antony, J. (2013). Applications of Lean Six Sigma in an Irish hospital. Leadership in Health Services, 26(4), 322-337. https://doi.org/10.1108/LHS-01-20120002

[30] Mader, D. P. (2008). LEAN SIX SIGMA'S EVOLUTION.

[31] Mancosu, P., Nicolini, G., Goretti, G., De Rose, F., Franceschini, D., Ferrari, C., ... Scorsetti, M. (2018). Applying Lean-Six-Sigma Methodology in radiotherapy: Lessons learned by the breast daily repositioning case. Radiotherapy and Oncology, 127(2), 326-331. https://doi.org/10.1016/j.radonc.2018.02.019

[32] Mandahawi, N., Al-Araidah, O., Boran, A., \& Khasawneh, M. (2011). Application of Lean Six Sigma tools to minimise length of stay for ophthalmology day case surgery. International Journal of Six Sigma and Competitive Advantage, 6(3), 156-172. https://doi.org/10.1504/IJSSCA.2011.039716

[33] Mason, S. E., Nicolay, C. R., \& Darzi, A. (2015). The use of Lean and Six Sigma methodologies in surgery: A systematic review. Surgeon. https://doi.org/10.1016/j.surge.2014.08.002

[34] Mazzocato, P., Holden, R. J., Brommels, M., Aronsson, H., Bäckman, U., Elg, M., \& Thor, J. (2012). How does lean work in emergency care? A case study of a lean-inspired intervention at the Astrid Lindgren Children's hospital, Stockholm, Sweden. BMC Health Services Research, 12(1). https://doi.org/10.1186/1472-6963-12-28

[35] Momani, A., Hirzallah, M., \& Mumani, A. (2013). Improving Employees 'Safety Awareness in Healthcare Organizations Using the DMAIC Quality Improvement Approach, 54-63.

[36] Montella, E., Di Cicco, M. V., Ferraro, A., Centobelli, P., Raiola, E., Triassi, M., \& Improta, G. (2017). The application of Lean Six Sigma methodology to reduce the risk of healthcare-associated infections in surgery departments. Journal of Evaluation in Clinical Practice. https://doi.org/10.1111/jep.12662

[37] Niemeijer, G., Trip, A., KTB, A., JMM, R., \& Wendt, K. (2010). Quality in trauma care: improving the discharge procedure of patients by means of Lean Six Sigma. Journals.Lww.Com Retrieved from https://journals.lww.com/jtrauma/fulltext/2010/09000/Quality_in Trauma Care Improving the Discharge.22.aspx

[38] Pocha, C. (2010). Lean six sigma in health care and the challenge of implementation of six sigma methodologies at a Veterans Affairs Medical Center. Quality Management in Health Care, 19(4), 312-318. https://doi.org/10.1097/QMH.0b013e3181fa0783

[39] Preethy, N., Diptee, O., Fretrik, A., \& Nguyen, anh t. (2013). Applying Lean Six Sigma to improve medication management. Nternational Journal of Health Care Quality Assurance, 20, 572 584. https://doi.org/10.1108/09526860710819440

[40] Proudlove, N., Moxham, C., \& Boaden, R. (2008). Lessons for lean in healthcare from using six sigma in the NHS. Public Money and Management, 28(1), 27-34. https://doi/abs/10.1111/j.1467-9302.2008.00615.x

[41] R., R., \& Mallikarjun, J. (2011). Six Sigma: Improving the Quality of Operation Theatre. Procedia - Social and Behavioral Sciences. https://doi.org/10.1016/j.sbspro.2011.10.547

[42] Schweikhart, S. A., \& Dembe, A. E. (2009). The Applicability of Lean and Six Sigma Techniques to Clinical and Translational Research. Journal of Investigative Medicine. https://doi.org/10.2310/JIM.0b013e3181b91b3a

[43] Steere, L., Rousseau, M., \& Durland, L. (2018). Lean Six Sigma for Intravenous Therapy Optimization: A Hospital Use of Lean Thinking to Improve Occlusion Management. JAVA - Journal of the Association for Vascular Access, 23(1), 42-50. https://doi.org/10.1016/j.java.2018.01.002

[44] Tagge, E. P., Thirumoorthi, A. S., Lenart, J., Garberoglio, C., \& Mitchell, K. W. (2017). Improving operating room efficiency in academic children's hospital using Lean Six Sigma methodology. Journal of Pediatric Surgery. https://doi.org/10.1016/j.jpedsurg.2017.03.035

[45] Tekes, A., E.M.Jackson, J.Ogborn, Liang, S., M.Bledsoe, D.J.Durand, T.A.G.M.Huisman. (2016). How to Reduce Head CT Orders in Children with Hydrocephalus Using the Lean Six Sigma Methodology: Experience at a Major Quaternary Care Academic Children's Center. 